\title{
Bahasa Sasak Alus Dan Bahasa Indonesia: Familiarisasi Bahasa Pinjaman Dalam Menumbuhkan Karakter Kesantunan Anak Usia Dini
}

\author{
Khirjan Nahdi ${ }^{1}$, Hamzani Wathoni ${ }^{2}$, Baiq Shofa Ilhami ${ }^{3}$ \\ PBSI Universitas Hamzanwadi ${ }^{1}$, PBI Universitas Hamzanwadi, PG PAUD \\ Universitas Hamzanwadi \\ kkirjan.nw@gmail.com¹, hamzanwathoni@gmail.com², \\ shofa.ilhami@gmail.com ${ }^{3}$
}

\begin{abstract}
Abstrak
Artikel ini mengkaji proses familiarisasi atau pengakraban Bahasa Sasak Alus ke dalam komunikasi Bahasa Indonesia anak usia dini. Melalui metode deskriptif dalam kajian sosiopragmatik, kajian ini bertujuan menemukan bentuk karakter kesantunan komunikasi dan proses pembentukan karakter kesantunan anak usia dini melalui bahasa pinjaman. Kajian ini strategis dalam dua hal sekaligus; pertama, proses pembentukan karakter dominan merupakan kegiatan yang disengaja dan disadari melalui sistem pembelajaran. Konteks kajian ini menunjukkan proses alamiah dan non indokrtinasi. Kedua, kajian sosiopragmatik selalu menempatkan proses peminjaman bahasa sebagai gangguan peristiwa berbahasa dalam konteks multibahasa. Konteks kajian ini menunjukkan adanya sumbangan positif terhadap penumbuhan kesantunan berbahasa sejak usia dini. Didahulu dengan teknik pengelompokan kelas kata dan penggambaran situasi komunikasi, ditemukan bahwa familiarisasi bahasa pinjaman Bahasa Sasak Alus ke dalam komunikasi Bahasa Indonesia menumbuhkan karakter kesantunan dalam berkomunikasi anak usia dini. Karakter dimaksud diperoleh melalui penggunaan kata pinjaman Bahasa Sasak Alus ke dalam komunikasi Bahasa Indonesia. Kata pinjaman terdiri atas lima kelas kata, yakni pronomina, interogativa, adverbia modalitas (kejadian), adverbia kuantitas (kala), dan demonstrativa. Kelima kelas kata tersebut diucapak dengan nada datar, parau, hingga menurun. Pengucapan kata-kata dengan nada tersebut mengandung empat motivasi, yakni merendahkan diri, menghargai lawan bicara, memosisikan diri sebagai bagian orang lain, dan melanjutkan komunikasi. Proses tersebut dilakukan sejak dini melalui proses inkulkasi atau penanaman karakter oleh orang dewasa melalui proses keteladanan.
\end{abstract}

Kata kunci: Familiarisasi, bahasa pinjaman, karakter, usia dini.

\section{Abstract}

This article examines the process of familiarization the Sasak Alus Language into Indonesian language communication in early childhood. Through descriptive methods in the sociopragmatic study, this study aims to find forms of communication politeness character and the process of forming the character of early childhood politeness through loan languages. This study is strategic in two ways; first, the process of forming dominant characters is a deliberate and conscious 
activity through the learning system. This study shows the natural process and nonindoctrination. Second, sociopragmatic studies always place the process of language lending as a disruption of language events in a multilingual context. This study shows a positive contribution to the growth of politeness in language from an early age. Previously with word class grouping techniques and the description of communication context, it was found that familiarization of the loan language of the Sasak Alus language into Indonesian communication fostered the character of politeness in communicating early childhood. Previously with word class grouping techniques and the description of the communication context, it was found that familiarization of the loan language of the Sasak Alus language into Indonesian communication fostered the character of politeness in communicating early childhood. This character is obtained through the use of the loan word Sasak Alus in Indonesian communication. The word loan consists of five classes of words, namely pronouns, interrogative, adverb modality (event), adverb quantity (tense), and demonstrative. The five classes of words are said in a flat, hoarse tone, until decrease. The pronunciation of words in that tone contains four motivations, namely to humble yourself, respect the other person, position yourself as part of others, and continue communication. The process is carried out early on through the process of inculcation of character by adults through the exemplary process.

Keywords: Familiarization, loan language, character, early childhood.

\section{PENDAHULUAN}

Istilah familiarisasi dalam kajian ini diambil dari istilah pengembangan sumber daya manusia oleh Kusuma (Siagian, 2020), yakni tindakan mengakrabkan sesuatu dalam proses sosial. (Noer, 2011) menyebutkan, familiarisasi sebagai salah satu tips membaca melalui pemilihan bacaan yang akrab dengan pembaca. Pinjaman bahasa merupakan kata lain dari borrowing, yakni istilah sosiolinguistik sebagaimana disebutkan Trudgill (1992); Crystal (1992) yang menggambarkan penutur multibahasa memasukkan kode satu bahasa ke dalam bahasa lain, dan dalam waktu lama keberadaan kode bahasa tersebut menjadi diterima sebagai satu kewajaran. Proses mengakrabkan kode-kode Bahasa Sasak Alus sebagai kode yang dipinjam dalam komunikasi Bahasa Indonesia dapat dikategorikan sebagai proses familiarisasi dalam kajian ini. Lumban Tobing (2013) dalam kajian tentang penggunaan kata sapaan bahasa Indonesia oleh siswa dalam berbagai kesempatan. Temuan penting Lumban Tobing, penggunaan kata sapaan tidak saja meningkatkan keterampilan berbahasa Indonesia melalui bentuk-bentuk sapaan, tetapi juga membangun sikap kesopanan dalam berbahasa. Ferdiawan \& Putra (2013) mengkaji proses pembentukan kecerdasan intelegensi, emosional, dan sosial (IESQ) melalui falsafah budaya Jawa. Temuan kajian Ferdiawan dan Eka Putra, proses humanisasi budaya Jawa sejak usia dini akan mengurangi berbagai masalah sosial dalam masyarakat Indonesia.

Kajian lain oleh Mei-Ju, Chen-Hsin, \& Pin-Chen (2014) terhadap proses pengasuhan anak usia dini di Taiwan melalui berbagai model, seperti kebiasaan membaca, mencintai musik, pengenalan lingkungan, dan transmisi nilai moral. 
Harrer, Kachalov, Borodin, \& Kachalova (2015) mengkaji pentingnya aspek sosial dan budaya bahasa sasaran dalam pembelajaran bahasa asing bagi anak usia dini. Menurut Harrer dkk., aspek sosial dan budaya bahasa asing dianggap strategis dalam meningkatkan penguasaan bahasa asing oleh anak usia dini. Jamaluddin (2013) menawarkan aspek lain kajiannya, yakni pentingnya pembentukan karakter dalam pendidikan melalui kristalisasi nilai-nilai Islam yang bersumber dari quran, hadist, dan penjelasan dari keduanya. Kajian khusus pembelajaran bahasa daerah untuk anak usia dini dilakukan oleh Wiranti, Afrianingsih, \& Mawarti (2018), tentang konstruksi moral anak usia dini melalui Bahasa Jawa Krama. Melalui kajian literatur ketiga peneliti ini melihat bahasa Jawa Krama strategis dalam membentuk fondasi moral anak usia dini sehingga penting dijadikan sebagai materi pembelajaran bahasa. Khotijah (2016); (Nahdi \& Yunitasari, 2019); dan (Nahdi \& Yunitasari, 2020) lebih menekankan kajian pada aspek strategi pembelajaran bahasa mengembangkan keterampilan menyimak, membaca, menulis, dan berbiara.

Kajian pembelajaran bahasa di atas, belum secara spesifik mempersoalkan karakter kesantunan melalui peminjaman bahasa daerah ke dalam bahasa nasional. Lumban Tobing berdiskusi tentang kesopanan dalam bahasa sapaan bahasa Indonesia. Ferdiawan dan Eka Putra mepersoalkan IESQ dalam falsafah budaya Jawa. Mei-Ju, dkk menemukan konstruksi karakter moral melalui pengasuhan. Harrer, dkk menemukan strategisnya aspek sosial bahasa asing yang dipelajari dalam mempercepat penguasaan bahasa asing tersebut. Jamaluddin menawarkan pentingnya nilai agama dalam pembentukan karakter. Demikian pula Khotijah, yang meawarkan berbagai strategi pembelajaran bahasa bagi anak usia dini, dan cenderung pada aspek keterampilan berbahasa. Kajian yang lebih dekat dengan kajian ini, oleh Wiranti, dkk., tentang fondasi karakter dalam Bahasa Jawa Krama. Hanya saja, kajiannya masih berkaitan dengan pembelajaran bahasa Jawa Krama sebagai materi khusus. Kajian familiarisasi Bahasa Sasak Alus sebagai bahasa pinjaman dalam bahasa Indonesia menjadi bukti lain dalam konteks multibahasa. Melalui perspektif selain sosiolinguistik, bahasa pinjaman memberikan efek positif dalam menumbuhkan kesantunan berbahasa, dan berpengaruh pada kesantunan lain. Karena itu, kajian ini bertujuan: 1) menemukan bentuk karakter kesantunan dalam kode Bahasa Sasak Alus yang dipinjam dalam Bahasa Indonesia pada proses familiarisasi terhadap anak usia dini; 2) bentuk familiarisasi kode Bahasa Sasak Alus dalam Bahasa Indonesia dalam membentuk karakter kesopanan anak usia dini. Urgensi kajian ini, proses familiarisasi menjadi alternatif pembentukan karakter kesantunan melalui bahasa yang dapat dilakukan oleh seluruh orang dewasa dalam relasinya terhadap anak usia dini. Proses ini merupakan strategi baru dalam pembelajaran karakter, dengan menemukan hal baru yang tidak terduga dalam relasi antarbahasa. Abdullah (2019) menyebutkan, temuan ini menjadi data baru dalam pembelajaran bahasa dan pembentukan karakter kesantunan anak usia dini. 


\section{Literatur Review}

\section{Kode Bahasa dan Karakter Kesantunan}

Kode bahasa dalam hal ini adalah kode Bahasa Sasak Alus sebagaimana dikatakan Wilian \& Husaini (2019) sebagai bagian dari variasi tutur dalam bahasa Sasak selain variasi madya dan biasa. Kode Bahasa Sasak Alus terkait dengan kata atau bentuk kata secara leksikal yang hadir dalam rangkaian gramatikal pada konteks komunikasi penutur bahasa (Leksono, 2009); (Samsuri, 1987); (Moeliono, 1988). Fokus kajian ini terkait dengan proses peminjaman kode bahasa Sasak Alus dalam komunikasi maka komunikasi yang dimaksud adalah pemakaian bahasa Indonesia dalam keluarga yang di dalamnya terjadi peminjaman kode Bahasa Sasak Alus, sebagaimana lazim dalam kajian sosiolinguistik (Holmes, 2012). Komunikasi semacam ini lazim ditemukan pada keluarga dengan orang tua berlatarbelakang bahasa pertama Bahasa Sasak, tetapi mengenalkan bahasa Indonesia sebagai bahasa pertama kepada anak-anak mereka. Dalam kasus ini, keluarga menjadi salah satu konteks pembelajaran kedwibahasaan awal, terutama pembelajaran bahasa daerah sebagai bahasa pertama dan bahasa nasional sebagai bahasa kedua (Tarigan, 1988). Kehadiran Bahasa Sasak Alus tanpa bercampur atau beralih kode dengan bahasa Indonesia sudah diyakini mengandung makna kesantunan, karena Bahasa Sasak sendiri memiliki variasi lain, yakni madya dan biasa.

Selain sebagai proses komunikasi yang menghadirkan bahasa pertama dan bahasa kedua, pilihan-pilihan kode bahasa melalui proses peminjaman mengandung maksud emosi penutur bahasa (Suprapti, Iswardani A, \& Sadli, 1992). Terkait pernyataan Suprapti, dkk., anak usia dini belum mampu menangkap makna emosi senang, sedih, susah, takut, bangga, dan sejenisnya, tetapi ekspresi psikologis akan ditunjukkan melalui peniruan kode dan nada bahasa orang dewasa. Peniruan anak usia dini atas kode dan nada bahasa orang dewasa, (Crain, 2007) menyebutnya sebagai proses imitasi, asosiasi, dan repitisi. Anak usia dini akan mengulangi sikap dan prilaku orang dewasa melalui penyesuaian kode atau konteks bahasanya. Crain menganggap usia dini sebagai usia emas dalam penumbuhan berbagai karakter positif, termasuk melalui kode bahasa yang memiliki kandungan karakter kesantunan. Lebih jauh, Crain mengungkapkan, penumbuhan karakter merupakan keseluruhan proses pembelajaran anak usia dini dalam lingkungan keluarga. Proses pembelajaran dimaksud harus mengakomodasi kehadiran tindakan penghukuman dan penghargaan terhadap pembelajar. Penumbuhan karakter kesantunan melalui peminjaman bahasa Sasak Alus harus terjadi terus menerus diikuti dengan penghargaan dan penghukuman.

\section{Karakter Kesantunan dan Proses Integrasi}

Karakter atau pendidikan karakter dalam proses pendidikan sebagaimana Langeveld merupakan upaya mengenalkan nilai hakiki pada manusia untuk mencapai kemandirian (Juneman, 2010). Kemandirian hanya akan diperoleh jika manusia memiliki pengetahuan, keterampilan, dan sikap. Dalam hubungan ketiganya, sikap terbukti dapat menjadi pemandu dalam pembentukan keutuhan kemandirian manusia. Pandangan Langeveld tentang karakter berujud kemandirian sejajar dengan pandangan Lickona (2012) dengan menyebut karakter sebagai 
kebajikan. Kebajikan sebagai nilai baik pada individu menjadikannya mampu menentukan arah dan agenda hidup secara mandiri. Instrumen strategis pengembangan karakter adalah pendidikan, sehingga karakter selalu dilekatkan dengan kata pendidikan (Pemerintah RI, 2010). Sebagai tanggung jawab pendidikan, pengenalan karakter, termasuk karakter kesantunan dapat diintegrasikan dalam proses berbahasa dan atau belajar berbahasa. Maksud ini beralasan karena belajar bahasa menurut Zuhdi, Kun Prasetyo, \& Siasah Masruri (2013) tidak saja bertujuan menguasai bentuk bahasa untuk berbagai keperluan, juga untuk membentuk karakter baik, budi pekerti luhur, dan akhlak mulia melalui inkulkasi dan keteladanan orang dewasa pada anak usia dini.

Lebih lanjut, satu prinsif penting dalam pembelajaran bahasa untuk menumbuhkan karakter menurut Zuhdi, dkk., adalah pembelajaran bahasa dalam konteks, termasuk pembelajaran bahasa kedua (bahasa nasional atau bahasa daerah) melalui peminjaman kode bahasa. Sejak dini, anak-anak sudah mendengarkan dan meniru kosa kata bahasa orang dewasa dalam proses sosialnya. Mendengarkan dan meniru kosa kata orang dewasa oleh anak usia dini tidak semata mengalihkan laras bahasa dalam hal kosa kata, frasa, maupun kalimat, tetapi penanaman nilai kebajikan atau karakter yang diwakili oleh bentuk laras bahasa yang digunakannya. Karakter kesantunan dalam konteks ini dapat berbentuk karakter menghargai orang lain, atau merendahkan diri di hadapan lawan bicara. Bentuk-bentuk karakter dimaksud dapat diujudkan melalui jenis pilihan kata, intonasi, tekanan, dan penempatan kata dalam keseluruhan komunikasi.

\section{METODE}

Kajian ini termasuk penelitian sosiopragmatik (sosiolinguistik dan pragmatik) dengan metode deskriptif (Sudaryanto, 1992). Secara sosiolinguistik, data kajian berbentuk kode Bahasa Sasak yang dipinjam dalam komunikasi bahasa Indonesia oleh orang dewasa kepada anak usia dini atau sebaliknya. Secara pragmatik, aspek yang diungkap berkaitan dengan kesantunan pada masing-masing kode Bahasa Sasak Alus yang dipinjam ke dalam Bahasa Indonesia. Instrumen kajian berbentuk catatan potret pemakaian bahasa dalam konteks alamiah yang menunjukkan kondisi peminjaman bahasa. Data penelitian dipilah berdasarkan kelas kata (Kridalaksana, 1990), dan dianalisis menurut tingkat kesantunan Levinson (Gunarwan, 1992). Kesantunan ditunjukkan melalui tekanan kata atau nada rendah atau tinggi pada bagian kata. Analisis kesantunan diikuti deskripsi inkulkasi (penanaman) dan keteladanan (pemberian contoh) karakter kesantunan masing-masing kode bahasa pinjaman. 


\section{HASIL DAN PEMBAHASAN}

\section{Data Penelitian}

Data kajian dibagi dalam dua kelompok, yakni kata Bahasa Sasak Alus yang dipinjam dalam komunikasi Bahasa Indonesia dan situasi komunikasi yang menghadirkan kode Bahasa Sasak Alus yang dipinjam dalam Bahasa Indonesia dengan konteks inkulkasi dan keteladanan karakter. Data yang dikumpulkan adalah kata-kata yang lazim sebagai kata pinjaman dalam Bahasa Indonesia. Lihat Tabel 1 dan 2.

Tabel 1: Kode bahasa Sasak Alus Pinjaman ke dalam Bahasa Indonesia

\begin{tabular}{|c|c|c|}
\hline Kelas Kata & $\begin{array}{l}\text { Fungsi dalam } \\
\text { Komunikasi }\end{array}$ & Pengucapan-Intonasi \\
\hline \multicolumn{3}{|c|}{ Pronomina (Kata Ganti) } \\
\hline Tiang 'saya' & $\begin{array}{l}\text { Pengganti nama diri } \\
\text { sebagai orang pertama } \\
\text { tunggal }\end{array}$ & $\begin{array}{l}\text { Nada turun, atau memanjang } \\
\text { pada akhir suku kata, } \\
\text { menjadi: tiaaang }\end{array}$ \\
\hline Plinggih 'anda' & $\begin{array}{l}\text { Pengganti nama diri } \\
\text { sebagai orang kedua } \\
\text { tunggal }\end{array}$ & $\begin{array}{l}\text { Nada datar, kadang turun } \\
\text { dengan dengan ucapan } \\
\text { memanjang pada akhir suku } \\
\text { kata, menjadi plinggiiih }\end{array}$ \\
\hline \multicolumn{3}{|c|}{ Interogativa (kata tanya) } \\
\hline Napi 'apa' & $\begin{array}{l}\text { Penguat pertanyaan } \\
\text { tentang sesuatu (benda } \\
\text { atau keadaan) }\end{array}$ & $\begin{array}{lr}\text { Nada datar, atau kadang turun } \\
\text { pada akhir suku kata } \\
\text { tergantung } & \text { kedalaman } \\
\text { maksud } & \text { interogasi } \\
\text { (pertanyaan), menjadi: napi, } \\
\text { atau napiii }\end{array}$ \\
\hline \multicolumn{3}{|c|}{ Adverbia Modalitas (keterangan kejadian) } \\
\hline Nggih 'ya' & $\begin{array}{l}\text { Penanda persetujuan atau } \\
\text { penerimaan (sesuatu atau } \\
\text { keadaan) }\end{array}$ & $\begin{array}{l}\text { Nada turun pada akhir suku } \\
\text { kata, kadang datar, } \\
\text { tergantung kejelasan kejadian } \\
\text { yang diterangkan, menjadi: } \\
\text { nggiih, atau nggih }\end{array}$ \\
\hline $\begin{array}{l}\text { Nenten } \\
\text { 'tidak/bukan' }\end{array}$ & $\begin{array}{l}\text { Penanda penolakan, tidak } \\
\text { setuju (sesuatu atau } \\
\text { keadaan) }\end{array}$ & $\begin{array}{l}\text { Nada datar, kadang turun } \\
\text { pada khir suku kata, } \\
\text { tergantung kejelasan kejadian } \\
\text { yang belum atau tidak terjadi, } \\
\text { menjadi: nenten, atau } \\
\text { nenteeen }\end{array}$ \\
\hline
\end{tabular}




\begin{tabular}{|c|c|c|}
\hline Kelas Kata & $\begin{array}{l}\text { Fungsi dalam } \\
\text { Komunikasi }\end{array}$ & Pengucapan-Intonasi \\
\hline \multicolumn{3}{|c|}{ Adverbia Kuantitas (keterangan kala) } \\
\hline Sampun 'sudah' & $\begin{array}{l}\text { Penunjuk sudah } \\
\text { terjadinya peristiwa }\end{array}$ & $\begin{array}{l}\text { Dada datar, kadang turun } \\
\text { pada akhir suku kata, } \\
\text { tergantung pada kejelasan } \\
\text { kala yang diterangkan, } \\
\text { menjadi: sampun, atau } \\
\text { sampuuun }\end{array}$ \\
\hline Mangkin 'sekarang' & $\begin{array}{l}\text { Petunjuk sedang atau akan } \\
\text { terjadinya peristiwa }\end{array}$ & $\begin{array}{l}\text { Nada datar, kadang turun } \\
\text { pada akhir suku kata, } \\
\text { tergantung pada kejelasan } \\
\text { kala yang diterangkan, } \\
\text { menjadi: mangkin, atau } \\
\text { mangkiiin }\end{array}$ \\
\hline \multicolumn{3}{|c|}{ Demonstrativa (penunjuk) } \\
\hline$N i k i$ 'ini' & $\begin{array}{l}\text { Pentunjuk keberadaan } \\
\text { objek, sesuatu pada jarak } \\
\text { dekat }\end{array}$ & $\begin{array}{l}\text { Nada datar, kadang turun } \\
\text { pada kahir suku kata, } \\
\text { tergantung pada kejelasaan } \\
\text { objek yang ditunjuk pada } \\
\text { jarak dekat, menjadi niki, } \\
\text { atau nikiii. }\end{array}$ \\
\hline Nike 'itu' & $\begin{array}{l}\text { Petunjuk keberadaan } \\
\text { objek, sesuatu pada jarak } \\
\text { lebih jauh }\end{array}$ & $\begin{array}{l}\text { Nada datar, kadang turun } \\
\text { pada kahir suku kata, } \\
\text { tergantung pada kejelasaan } \\
\text { objek yang ditunjuk pada } \\
\text { jarak agak jauh, menjadi nike, } \\
\text { atau nikeee. }\end{array}$ \\
\hline
\end{tabular}

Tabel 2: Situasi Komunikasi, Inkulkasi dan Keteladanan Karakter

\begin{tabular}{|c|c|c|}
\hline & l In & $\begin{array}{l}\text { Model Kete } \\
\text { Karakter Kesa }\end{array}$ \\
\hline $\begin{array}{l}\text { mobil- mobilan tiang? } \\
\text { Ibu/Bapak: di mana? } \\
\text { Kan plinggih yang } \\
\text { simpan! }\end{array}$ & $\begin{array}{l}\text { menanamkan karakter } \\
\text { santun dan lemah } \\
\text { lembut dalam bertutur } \\
\text { kata dalam menyebut } \\
\text { pronominal dirinya } \\
\text { 2. Anak mengikuti } \\
\text { 3. Ibu/bapak } \\
\text { menanamkan karakter }\end{array}$ & $\begin{array}{l}\text { 1. Ibu-bapak menjadi } \\
\text { contoh karakter } \\
\text { santun dan lemah } \\
\text { lembut } \\
\text { bertutur kata dalam } \\
\text { menyebut nama diri } \\
\text { 2. Anak mengikuti } \\
\text { 3. Ibu-bapak menjadi } \\
\text { contoh karakter }\end{array}$ \\
\hline
\end{tabular}




\begin{tabular}{|c|c|c|}
\hline Situ & $\begin{array}{l}\text { Model Inkulkasi } \\
\text { Karakter Kesantunan }\end{array}$ & $\begin{array}{l}\text { Model Keteladanan } \\
\text { Karakter Kesantunan }\end{array}$ \\
\hline $\begin{array}{l}\text { Anak: ibu/bapak!! } \\
\text { Ibu/bapak: napiii lagi? } \\
\text { Anak: mana? } \\
\text { Ibu/Bapak: nggih, } \\
\text { mangkin dicarikan! } \\
\text { Anak: itu di atas tivi! } \\
\text { Ibu/bapak: nenten! } \\
\text { Bapak/Ibu: } \\
\text { ketemu? } \\
\text { Bapak/Ibu: mangkin } \\
\text { dulu! } \\
\text { Bapak/Ibu: di atas } \\
\text { tempat tidur nike, } \\
\text { Bapak/ibu: oooo, niki- } \\
\text { niki ketemu! }\end{array}$ & $\begin{array}{l}\text { santun dan lemah } \\
\text { lembut dalam bertutur } \\
\text { kata dalam menyebut } \\
\text { pronominal nama } \\
\text { anaknya } \\
\text { 4. Ibu/bapak } \\
\text { menanamkan karakter } \\
\text { santun dan lemah } \\
\text { lembut dalam bertutur } \\
\text { kata dalam menyebut } \\
\text { modal kala/waktu } \\
\text { 5. Ibu/bapak } \\
\text { menanamkan karakter } \\
\text { santun dan lemah } \\
\text { lembut dalam bertutur } \\
\text { kata dalam menyebut } \\
\text { modalitas kejadian } \\
\text { 6. Ibu/bapak karakter } \\
\text { menanamkan karakt lemah } \\
\text { santun dan bertutur } \\
\text { lembut dalam be jauh- } \\
\text { kata dalam menyebut } \\
\text { demonstrativa jauh } \\
\text { dekat }\end{array}$ & $\begin{array}{lr}\begin{array}{l}\text { santun dan } \\
\text { lembut }\end{array} & \begin{array}{l}\text { lemah } \\
\text { dalam }\end{array} \\
\text { bertutur kata } & \text { dalam } \\
\text { menyebut pronominal } & \\
\text { anaknya } & \\
\text { 4. Ibu-bapak } & \text { menjadi } \\
\text { contoh } & \text { karakter } \\
\text { santun dan } & \text { lemah } \\
\text { lembut } & \text { dalam } \\
\text { bertutur kata } & \text { dalam } \\
\text { menyebut } & \text { modal } \\
\text { kala/waktu } & \\
\text { 5. Ibu-bapak } & \text { menjadi } \\
\text { contoh } & \text { karakter } \\
\text { santun dan } & \text { lemah } \\
\text { lembut } & \text { dalam } \\
\text { bertutur kata } & \text { dalam } \\
\text { menyebut } & \text { modal } \\
\text { kejadian } & \\
\text { Ibu-bapak ran } & \text { menjadi } \\
\text { contoh karakter } & \text { santun } \\
\text { dan lemah lembut dalam } \\
\text { bertutur kata } & \text { dalam } \\
\text { menyebut demonstrativa } \\
\text { jauh-dekat }\end{array}$ \\
\hline
\end{tabular}

Familiarisasi Kode Bahasa Sasak Alus sebagai Bahasa Pinjaman ke dalam Bahasa Indonesia

Mengacu salah satu istilah kunci kajian ini, familiarisasi atau pengakraban kode Bahasa Sasak Alus dalam Bahasa Indonesia dalam komunikasi keluarga, antara orang tua dan anak usia dini secara resiprokal (bolak-balik). Secara sosiolingusitik, penggunaan kode Bahasa Sasak Alus dalam Bahasa Indonesia merupakan proses peminjaman kode bahasa. Penggunaan kode tersebut secara terus menerus tanpa disadari sebagai proses peminjaman merupakan proses komunikasi pragmatis, sehingga kajian ini termasuk jenis sosiopragmatik. Kehadiran kode pinjaman Bahasa Sasak Alus ke dalam Bahasa Indonesia sebagaimana tabel 1, disesuaikan dengan perkembangan fisik dan psikis anak usia dini, sehingga katakata pinjaman adalah kosa kata dasar sesuai kelas katanya. Terdapat lima kelas kata yang sering digunakan dalam proses familiariasasi bahasa pinjaman. Pertama, pronomina (pertama dan kedua tunggal), yakni tiang 'aku/saya' dan plinggih 
'kamu'. Kedua kata ganti ini mucul dalam gabungan komunikasi Bahasa Indonesia antara orang tua dan anak usia dini untuk menyebut nama diri masing-masing. Kedua, interogativa, yakni napi 'apa', biasa digunakan untuk memperkuat pertanyaan yang menekankan sesuatu. Ketiga, adverbia modalitas kejadian, yakni nggih 'ya' dan nenten 'bukan/tidak' yang keduanya digunakan untuk maksud memastikan sesuatu atau bukan sesuatu yang didmaksud dalam komunikasi. Keempat, adverbial kuantitas, yakni sampun 'sudah' dan mangkin 'sekarang' untuk menyatakan kejadian sudah atau sedang berlangsung. Kelima, demonstrativa, yakni niki 'ini' atau nike 'itu' untuk menyatakan maksud keberadaan sesuatu atau benda pada jarak dekat atau jarak jauh.

Sebagai proses sosiopragmatik melalui familiarisasi dalam membentuk karakter kesantunan dalam berbahasa, kosa kata pinjaman tersebut diucapkan dengan nada datar, parau, bahkan cenderung menurun. Nada datar, parau, atau menurun bisa dilakukan pada kosa kata pinjaman atau pada keseluruhannya sebagai gabungan bahasa pinjaman dan Bahasa Indonesia. nada datar, parau, atau menurun, baik pada kata tersebut atau keseluruhannya dimaksudkan untuk membangun karakter kesantunan anak usia dini melalui "merendahkan diri di hadapan orang lain, menghargai lawan bicara, apalagi lawan bicara adalah orang yang lebih tua, memosisikan diri sebagai bagian orang lain, yakni lawan bicara, dan menjaga kelangsungan komunikasi", Jadi, melalui bentuk kata dan nada berbahasa terdapat empat motivasi yang dibangun sebagai karakter kesantunan anak usia dini, yakni sikap merendah, menghargai orang lain, berusaha menjadi bagian dari orang lain, dan menjaga kelangsungan komunikasi. Dalam kenyataannya, bentuk kata pada masing-masing kelas kata tersebut tidak pernah diucapkan dengan nada pendek dan tinggi, selalu sebaliknya. Jika kata-kata tersebut diucapkan pendek dan nada tinggi, akan kedengaran aneh. Dalam jangka panjang, proses pengucapan dengan nada datar, parau, dan menurun dengan tiga motivasi komunikasi merupakan proses familiarisasi untuk maksud membentuk karakter kesantunan anak usia dini.

\section{Familiarisasi melalui Inkulkasi dan Keteladanan Karakter Kesantunan}

Familiariasasi Bahasa Sasak Alus yang dipinjam dalam komunikasi Bahasa Indonesia secara resiprokal antara orang tua dan anak usia dini, sebagaimana tampak pada tabel 2, disadari atau tidak disadari menjadi proses penanaman atau inkulasi karakter kesantunan pada anak usia dini. Melalui empat motivasi komunikasi sebagai fondasi karakter kesantunan melalui peminjaman kode Bahasa Sasak Alus ini, terjadi penciptaan suasana kesetaraan antara anak usia dini dan orang tua. Dengan nada datar, parau, bahkan menurun, orang tua menanamkan kesantuan dalam komunikasi dengan orang lain. Suasana kesetaraan melalui keempat motivasi komunikasi tersebut merupakan proses inkulkasi atau penanaman karakter kesantunan berbahasa sejak usia dini. Inkulkasi sejak dini ini akan menciptakan pengalaman sosial yang santun secara alamiah, tanpa proses ekstrim melalui indoktrinasi tentang kesantunan melalui proses berbahasa. Karakter kesantunan melalui berbahasa dalam konteks sosial sejak usia dini. Penanaman sejak dini dengan empat motivasi komunikasi melalui familiarisasi ini diyakini 
akan menjadikan kesantunan tersebut menjadi karakter yang menjadi milik anak usia dini sebagai warna pribadinya menuju tahap perkembangan selanjutnya, menjadi anak-anak, remaja, hingga dewasa.

Selain inkulkasi sejak usia dini, motivasi komunikasi yang membentuk karakter kesantunan, proses sosiopragmatik secara resiprokal antara anak usia dini dan orang dewasa dilakukan pertama kali oleh orang dewasa. Anak usia dini mereplikasi ujaran kosa kata orang dewasa menjadi miliknya. Selanjutnya kepemilikan itu menjadikannya terbiasa berkomunikasi dengan kosa kata tersebut dengan nada yang biasa ditirukannya. Proses yang dilakukan orang dewasa ini merupakan proses peneledanan. Orang tua tidak saja memberi contoh tentang kelas kata yang digunakan dalam berkomunikasi, tetapi juga menjadi contoh dalam pengucapan kata dengan nada datar, parau hingga menurun. Masing-masing pihak yang berkomunikasi tidak pernah menyadari bahwa tindakan komunikasi dengan motif tersebut merupakan proses keteladanan. Proses tersebut berjalan secara alamiah dalam konteks komunikasi alamiah, dan lambat laun akan mempengaruhi karakter anak usia dini berkomunikasi secara santun dengan lawan bicaranya. Proses keteladanan seperti ini dibuktikan melalui perubahan prilaku komunikasi dengan karakter santun dalam proses komunikasi lain pada konteks yang lain.

\section{KESIMPULAN}

Berdasarkan data dan analisis, disimpulkan bahwa familiarisasi atau pengakraban kode Bahasa Sasak Alus sebagai bahasa Pinjaman dalam komunikasi Bahasa Indonesia antara anak usia dini dan orang tua secara resiprokal akan melahirkan karakter kesantunan dalam berkomunikasi anak usia dini Karakter kesantunan diperoleh melalui penggunaan kosa kata pinjaman dari kelas kata Bahasa Sasak Alus yang sederhana, yakni peminjaman pronominal, interogativa, adverbial modalitas (kejadian), adverbial kuantitas (kala), dan demonstrativa. Peminjaman dan pemakaian kelima kelas kata Bahasa Sasak Alus dalam komunikasi Bahasa Indonesia mengandung empat motivasi berbahasa anak usia dini, yakni merendahkan diri, menghargai lawan bicara, memosisikan diri sebagai bagian orang lain, dan melanjutkan komunikasi. Keempat motivasi komunikasi anak usia dini tersebut ditunjukkan melalui nada bicara yang datar, parau, bahkan menurun. Keempat motivasi komunikasi anak usia dini tersebut secara sosiopragmatik menunjukkan karakter kesantunan komunikasi yang diinkulkasi atau ditanamkan dan diteladankan olah orang dewasa melalui proses alamiah tanpa proses indoktrinasi.

\section{Referensi}

Abdullah; Ade Gaffar. (2019). Dari Riset sampai Naskah: Panduan Penulisan Artikel Ilmiah untuk Mahasiswa, Dosen dan Peneliti (1st ed.). Bandung: Rumah Publikasi Indonesia.

Crain, W. (2007). Teori Perkembangan: Teori dan Aplikasi (3rd ed.; S. Z. Qudsy, 
Ed.). Jogyakarta: Pustaka Pelajar.

Crystal, D. (1992). A Dictionary of Linguistics dan Phonetics (3rd ed.; et al Mc. Tear, Micahel, Ed.). Cambridge: Blackwell References.

Ferdiawan, E., \& Putra, W. E. (2013). Esq Education for Children Character Building based on Phylosophy of Javaness in Indonesia. Procedia - Social and Behavioral Sciences, 106, 1096-1102. https://doi.org/10.1016/j.sbspro.2013.12.123

Gunarwan, A. (1992). Persepsi Kesantunan Direktif dalam Bahasa Indoneisa di Antara Beberapa kelompok Etnik di Jakarta. In B. K. (ed) Purwo (Ed.), PELLBA 5 (1st ed., pp. 179-205). Jakarta: Unika Atmajaya.

Hardianti, F. (2019). Alat Permainan Edukatif Scrabble Untuk Meningkatkan Kemampuan Membaca Permulaan Anak Kelompok B. Jurnal Golden Age, 3(01), 17-29.

Harrer, I. A. C., Kachalov, N. A., Borodin, A. A., \& Kachalova, O. I. (2015). Sociocultural component in the content of teaching foreign languages to preschool children. Procedia - Social and Behavioral Sciences, 166, 344-350. https://doi.org/10.1016/j.sbspro.2014.12.534

Holmes, J. (2012). an introduction to socioliguistics. In The Modern Language Journal (fourth edi, Vol. 77). https://doi.org/10.2307/329116

Jamaluddin, D. (2013). Character Education In Islamic Perspective. International Journal of Scientific \& Technology Research, 2(2), 187-189.

Juneman. (2010). Lembaga Pendidikan Tinggi Tenaga Kependidikan (LPTK) Dalam Tantangan: Konvergensi Ilmu Pendidikan dengan Psikologi Sosial Serta Hikmah Pembelajaran Lintas Budaya Dalam Merajut Proses Pendidikan Berkarakter dan Berbudaya. Proceedings of The 4th International Conference on Teacher Education; Joint Conference UPI \& UPSI Bandung, Indonesia, 810 November 2010. Bandung: UPI.

Khotijah. (2016). Strategi Pengembangan Bahasa pada Anak Usia Dini. Elementary, 2(2016), 35-44.

Kridalaksana, H. (1990). Kelas Kata dalam Bahasa Indonesia (2nd ed.). Jakarta: Gramedia.

Leksono, K. (2009). Bahasa daerah di Indonesia. Surabaya: Universitas Negeri Surabaya.

Lickona, T. (2012). Action in Teacher Education Character Education: Seven Crucial Issues. (October 2014), 37-41. https://doi.org/10.1080/01626620.1999.10462937

Lumban Tobing, R. (2013). How to Say "Hello" in Indonesian Language (Teaching Indonesian Address Term ). Procedia - Social and Behavioral Sciences, 103, 449-458. https://doi.org/10.1016/j.sbspro.2013.10.359

Mei-Ju, C., Chen-Hsin, Y., \& Pin-Chen, H. (2014). The Beauty of Character 
Education on Preschool Children's Parent-child Relationship. Procedia Social and Behavioral Sciences, 143, 527-533. https://doi.org/10.1016/j.sbspro.2014.07.431

Moeliono, A. M. (1988). Tata Bahasa Baku Bahasa Indonesia (1st ed.). Jakarta: Balai Pustaka.

Nahdi, K., \& Yunitasari, D. (2019). Inside-Outside Circle: An Early Childhood Language and Literacy Development Method. 5(6), 325-335.

Nahdi, K., \& Yunitasari, D. (2020). Jurnal Obsesi : Jurnal Pendidikan Anak Usia Dini Literasi Berbahasa Indonesia Usia Prasekolah: Ancangan Metode Dia Tampan dalam Membaca Permulaan Abstrak. 4(1), 434-441. https://doi.org/10.31004/obsesi.v4i1.372

Noer, M. (2011). Teknik Membaca Cepat. Retrieved July 10, 2020, from membacacepat.com website: https://www.membacacepat.com/artikel/tipsmembaca-dan-memahami-lebih-cepat/

Pemerintah RI. (2010). Kebijakan Nasional Pembangunan Budaya dan Karakter Bangsa. Jakarta: Sekretariat Negara RI.

Samsuri. (1987). Analisis Bahasa (5th ed.). Jakarta: Erlangga.

Siagian. (2020). Familiarisasi. Retrieved July 10, 2020, from Scribd.com website: https://id.scribd.com/document/408048694/Definisi-Familiarisasi

Sudaryanto. (1992). Metode Linguistik: Ke Arah Memahami Metode Linguistik (1st ed.). Yogjakarta: UGM Press.

Suprapti, S. M. ., Iswardani A, T., \& Sadli, S. (1992). Leksikon dan Taksonomi Emosi. In B. K. Purwo (Ed.), PELLBA 5 (1st ed., pp. 97-105). Jakarta: Unika Atmajaya.

Tarigan, H. G. (1988). Pengajaran Kedwibahasaan (1st ed.). Bandung: Angkasa.

Trudgill, P. (1992). Introducing Language and Society (1st ed.; D. Crystal, Ed.). London: Penguin Books.

Wilian, S., \& Husaini, B. N. (2019). Pergeseran Pemakaian Tingkat Tutur (Basa Alus) Bahasa Sasak Di Lombok. Linguistik Indonesia, 36(2), 161-185. https://doi.org/10.26499/li.v36i2.82

Wiranti, D. A., Afrianingsih, A., \& Mawarti, D. A. (2018). Perkembangan Moral Anak. ThufuLA, 6(1).

Zuhdi, D., Kun Prasetyo, Z., \& Siasah Masruri, M. (2013). Model Pendidikan Karakter Terintegrasi dalam Pembelajaran dan Pengembangan Kultur Sekolah (1st ed.; S. La Ode, Ed.). Yogjakarta: Multi Presindo. 